\title{
Towards an Identification and Classification of Service Quality Attributes in Higher Education
}

\author{
Ronald Sukwadi, Ching-Chow Yang, and Fan Liu
}

\begin{abstract}
In what has become a highly competitive environment, students have become more discriminating in their selection and more demanding of the universities they choose. It is important then for institutions to understand service quality attributes what incoming students desire (and increasingly expect) from the institution of their choice. Higher education (HE) institutions should ensure that all services encounters are managed to enhance students' perceived quality. While there is a consensus on the importance of service quality issues in $\mathrm{HE}$, the identification and classification of the service quality attributes is a challenge to gain a better understanding of the quality issues of students' experiences face. The aim of this study is to identify and classify the service attributes that can promote student satisfaction. The process of identification and classification is demonstrated empirically in a case study of a well-known private university in Indonesia.
\end{abstract}

Index Terms_-identification, classification, service quality, higher education.

\section{INTRODUCTION}

Service quality is important to all organizations as it is "regarded as a driver of corporate marketing and financial performance" [1]. It has also been put forward as a critical determinant of competitiveness [2], and a source of lasting competitive advantage through service differentiation [3]. More people hear about poor customer service experience than good customer service, and negative word of mouth can have a devastating effect on an organization's efforts to attract new customers. Customers who have experienced poor service will reveal their experience to other people, and therefore this is likely to lead to a reduction in potential customers [4]. While public sector customers may not have the choices available in the private sector, poor service can still have a negative effect on reputation.

Service quality, emphasizing consumer satisfaction, is a newly-emerging field of concern. In order to attract customers, serve their needs and retain them, service providers and researchers are actively involved in understanding consumers' expectations and perceptions of service quality. Service quality is a feature of the literature in

Manuscript received June 20, 2011; Revised July 13, 2011.

Ronald Sukwadi is with the Industrial and Systems Department, Chung Yuan Christian University, Chung Li, Taiwan, on leave from the Industrial Engineering Department, Atma Jaya Catholic University, Jakarta, Indonesia (e-mail: ronaldmanutd@yahoo.com).

Ching-Chow Yang is with the Industrial and Systems Department, Chung Yuan Christian University, Chung Li, Taiwan (e-mail: chinchow@cycu.edu.tw).

Fan Liu is with the School of Management, Kyung Hee University, Seoul, South Korea (e-mail: imfanliu@gmail.com). marketing and operations management, but is just starting to gain attention in higher education [5].

Education sector is expanding very rapidly all over the world in recent years. Higher education (HE) is being driven towards commercial competition imposed by economic forces resulting from the development of global education markets [6]. The brisk increase in the number of institutions in higher education has led to an intense competition. Number of new institutions has been established and enrolment is also on the rise [5]. In this competitive environment only those institutions can excel which are providing quality education and constructive environment to their students, since these factors can influence their choice of admission. Such factors can satisfy students to their institutions and can affect their decisions to attend [7].

The role of service quality in HE has received increasing attention during the last two decades. HE institutions should ensure that all services encounters are managed to enhance consumer perceived quality [8]. While there is a consensus on the importance of service quality issues in $\mathrm{HE}$, the identification of service quality attributes and implementation of the right measurement tool are a challenge that practitioners who aim to gain a better understanding of the quality issues of students' experiences face [9]. In fact, the use of the most appropriate evaluation tool would help managers to assess service quality provided by their institutions, thus having the ability to use the results to better design service delivery [10],[11].

Many HE institutions perform some identifications of the service quality of education provided to students, as well as an assessment of student satisfaction. The subject of identifying service quality attributes is emphasized by several studies. More recently, several researchers have explored the subjects with varying perspectives and using different methodologies. The SERVQUAL has been used to determine critical attributes of various services and the improvement actions are derived based on gap score of expectation and perception [12],[13]. SERVQUAL has emerged as perhaps the most popular standardized questionnaires to measure service quality.

Furthermore, the Kano method is a powerful way to classify categories of quality attributes as customer requirements is widely used by various industries and many researchers. It provides a rough sketch of the customer's satisfaction in relation to the service performance level [14],[15]. However, Kano model has a deficiency that prevents service providers from precisely evaluating the influences of quality attributes. The refined Kano's model had presented by Yang further improved the Kano's model to categorize quality attribute more precisely in order to provide 
more accurate information [16].

This paper outlines the results of a study conducted on the university to obtain students' perspective on the service quality of educational institutions. The focus of the study has been on first, identifying service quality attributes in higher education; and, second, on proposing a framework of service attributes classification able to determine appropriate improving actions for service quality attributes in education. With the conceptualization, implementation and assessment of quality in education being very complex, it was essential to fall back on multiple tools in research methodology to arrive at a consensus; the SERVQUAL was applied to identify the service attributes and to determine the satisfaction level of service quality; and the refined Kano model was applied to evaluate and classify the patterns of quality, based on students' satisfaction with specific quality attributes and their degree of sufficiency. The practical application of the proposed methodology is demonstrated empirically in a case study of a private university in Indonesia.

\section{LITERATURE REVIEW}

\section{A. Service Quality}

There is no consensus on how to conceptualize service quality because of the difficulties involved in delimiting and measuring the construct [13],[17]. Definitions of service quality hold that this is the result of the comparison that customers make between their expectation and perception of the way the service has been performed [13], [17], [18]. Based on the service quality gaps, the service provider can determine the service quality improvement plans to improve customer satisfaction. Assessing service quality using SERVQUAL involves computing the difference between perception score and expectation score obtained from the questionnaire survey to the customers [17].

Parasuraman et al. [13] developed a multiple-item scale for measuring service quality. The SERVQUAL method uses the questionnaire consisting of 22 pairs of quality attributes based around 5 key dimensions:

1) Reliability: ability to perform the promised service dependably and accurately

2) Responsiveness: willingness to help customers and provide prompt service.

3) Assurance: knowledge and courtesy of service providers and their ability to convey trust and confidence

4) Empathy: the firm provides care and individualized attention to its customers.

5) Tangibles: appearance of physical facilities, equipment, personnel, and communication materials

In the context of higher education, these dimensions include the ability of the university to perform the promised service dependably and accurately (reliability), the willingness of the university to help students and provide prompt service (responsiveness), the knowledge and courtesy of teachers and their ability to convey trust and confidence (assurance), the caring, individualized attention the university provides its students with (empathy), and the appearance of the university's physical facilities, equipment, personnel, and communication materials (tangibles)
[19],[20].

\section{B. Kano and refined Kano model}

Kano model was inspired from Herzberg's motivator-hygiene model as two-dimensional (or 'two-way') model [14]. This model identified the quality attributes into five categories:

1) Attractive quality attributes: attributes that give satisfaction if present, but that result in no dissatisfaction if absent;

2) One-dimensional quality attributes: attributes characterized by a linear relationship between the customers' perception of satisfaction and the degree of fulfillment of the attributes;

3) Must-be quality attributes: attributes whose absence will result in customer dissatisfaction, but whose presence does not significantly contribute to the customer satisfaction;

4) Indifferent quality attributes: attributes that result in neither satisfaction nor dissatisfaction, regardless of being fulfilled or not; and

5) Reverse quality attributes: attributes that result in dissatisfaction when fulfilled and in satisfaction when not fulfilled.

Kano's model has many applications. The Kano model has the advantages in classifying customer needs [15],[16]. However, trade-offs are sometimes necessary. If some service attributes cannot be met simultaneously for technical or financial reasons, the service providers should consider other criteria that have the greatest influence on customer satisfaction. To solve this problem, Yang [16] proposed a refined Kano model by considering the degree of importance of the attributes as a perceived quality by customers. The degrees of importance were classified into two categories. If the degree of importance of an attribute was greater than the mean of the importance degree for all service quality attributes, that attribute had 'high' importance degree. It had 'low' importance degree if below the mean.

By adding the degree of importance, this refined model can help service providers in precisely evaluating the influences of various service quality attributes. The model effectively subdivided each of Kano's first four main categories - thus making a total of eight categories from the original four. In addition, the existence of a ninth category, Kano's category of 'reverse' attributes should also be noted. The redefinition of the categories of quality attributes according to the refined model allows service providers to make quality decisions with more precision [16]. Table 1 lists the redefined categories of quality attributes obtained by refining the Kano model. Yang [16] represented these quality attributes as illustrated in Fig. 1.

TABLE I: CATEGORIES IN REFINED KANO MODEL

\begin{tabular}{|l|l|l|}
\hline \multicolumn{1}{|c|}{$\begin{array}{c}\text { Categories of Kano } \\
\text { Model }\end{array}$} & High Importance & Low Importance \\
\hline $\begin{array}{l}\text { Attractive } \\
\text { One-dimensional }\end{array}$ & Highly attractive & Less attractive \\
Must be & High value-added & Low value-added \\
Indifferent & Critical & Necessary \\
\hline
\end{tabular}




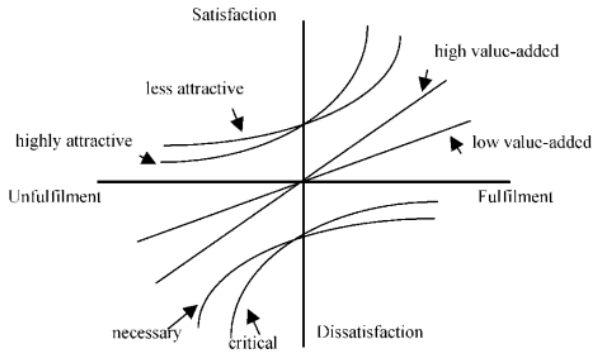

Fig. 1. Refined Kano model of quality attributes

\section{STRATEGIC IMPROVING ACTIONS}

In the past, service providers have undertaken improvement activities in their service offerings on the basis of customer satisfaction surveys, giving priority to improving the service items that record a low degree of satisfaction [21]. If higher education institutions as service providers simultaneously conduct evaluations of satisfaction and importance on pre-determined service items, they can then prioritize their improvement strategies appropriately to increase student satisfaction.

The determination of the categories of service items under refined Kano's model requires a customer survey using a questionnaire of the type developed by Kano et al. [10] and Yang [11]. In addition, higher education institution need to conduct surveys of student satisfaction and importance levels for a set of pre-determined service quality attributes. Having conducted these surveys, providers can proceed to make decisions on these attributes as described in Fig. 2.

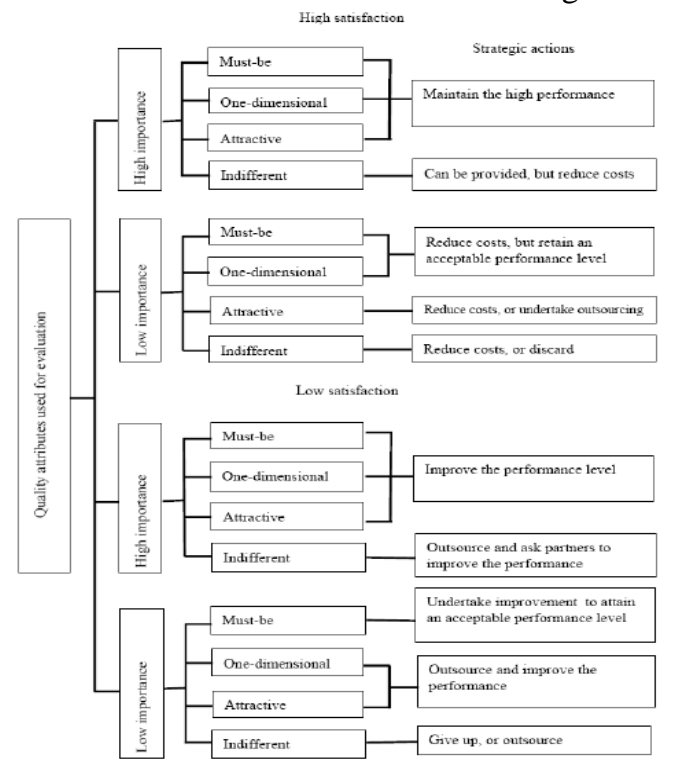

Fig. 2. Strategic improving actions based on categories of refined Kano model and satisfaction level

\section{EMPIRICAL CASE STUDY}

\section{A. Research Design}

In this research, an Indonesian well-established private university will be used for further discussion. Questionnaires were designed according to the SERVQUAL dimensions of measuring service quality. The questionnaires consisted of three main sections: (1) statements focused on student satisfaction level of service quality attributes, (2) statements focused on importance degree of service quality attributes, and (3) functional-disfunctional statements for refined Kano category classification. For the first two measures, Likert-type scales from ' 1 ' to as 'extremely unimportant (or very unsatisfied)' to '5' as 'very important (or very satisfied)' were used. For the third measure, the methodology suggested by Kano et al. [10] was used.

A pilot study of a sample size of 50 was conducted at university environment to ensure the user-friendliness of the designed questionnaires. 400 undergraduate students from different faculties were surveyed for this study, 384 returned usable questionnaires giving a response rate of 96 percent. All data were collected over a period of 3 months.

\section{B. Identification of Service Quality Attributes in HE}

Firstly, a total of 30 students were randomly interviewed to think of learning experiences in university. At the same time, the nominal group technique was used to conduct a panel discussion involved university stakeholders. The interview and discussion material were derived from five SERVQUAL dimensions. As a result, 5 higher education dimensions (consists of 29 service attributes) developed for this study are set out in Table 2.

TABLE II: SERVICE QUALITY ATTRIBUTES IN HIGHER EDUCATION

\begin{tabular}{|c|c|}
\hline $\begin{array}{c}\text { SERVQUAL } \\
\text { Dimensions }\end{array}$ & Service Attributes \\
\hline $\begin{array}{c}\text { A. } \\
\text { Reliability }\end{array}$ & $\begin{array}{l}\text { 1. The university makes a commitment to } \\
\text { provide a service at the scheduled time. } \\
\text { 2. The university keeps their records } \\
\text { accurately } \\
\text { 3. Relevant and up to date literature and } \\
\text { lecture material } \\
\text { 4. Literatures and lecture materials can be } \\
\text { easily understood. } \\
\text { 5. Good and understandable teaching } \\
\text { performance. }\end{array}$ \\
\hline $\begin{array}{c}\text { B. } \\
\text { Responsivenes } \\
\text { s }\end{array}$ & $\begin{array}{l}\text { 1. Important announcement is quickly } \\
\text { informed to students } \\
\text { 2. The university is always ready to help } \\
\text { students. } \\
\text { 3. Clear notice about assignments and } \\
\text { exams. } \\
\text { 4. Lecturers recommend appropriate text } \\
\text { book. } \\
\text { 5. The university provides consultation time } \\
\text { for students. }\end{array}$ \\
\hline $\begin{array}{c}\text { C. } \\
\text { Assurance }\end{array}$ & $\begin{array}{l}\text { 1.Lecturers have the required knowledge } \\
\text { and education/competency } \\
\text { 2. Students are equipped with good quality } \\
\text { to work. } \\
\text { 3. Availability of career service for } \\
\text { graduates. } \\
\text { 4. Safe environment. } \\
\text { 5. Lecturers have the ability to answer } \\
\text { questions from students. } \\
\text { 6. Friendly environment and respect each } \\
\text { other. }\end{array}$ \\
\hline $\begin{array}{c}\text { D. } \\
\text { Empathy }\end{array}$ & $\begin{array}{l}\text { 1. Lecturers give relevant and appropriate } \\
\text { tasks. } \\
\text { 2. The availability of scholarship for } \\
\text { students with good achievement. } \\
\text { 3. Ease of obtaining lecture material. } \\
\text { 4. Ease of administration related with the } \\
\text { curriculum } \\
\text { 5. The university gives individual attention } \\
\text { to each student. } \\
\text { 6. Effective communication between }\end{array}$ \\
\hline
\end{tabular}




\begin{tabular}{|c|c|}
\hline & university and students. \\
\hline $\begin{array}{c}\text { E. } \\
\text { Tangibles }\end{array}$ & $\begin{array}{l}\text { 1. The university provides the facilities that } \\
\text { can be used to develop students' interest } \\
\text { and talent } \\
\text { 2. Employees should be well-dressed, appear } \\
\text { neat, and professional. } \\
\text { 3. The university provides the up to date } \\
\text { equipments to support learning process } \\
\text { 4. Clean environment (classroom, toilet, } \\
\text { canteen, etc.). } \\
\text { 5. Library provides up to date learning } \\
\text { source (e.g. books, journal, etc.). } \\
\text { 6. Campus cafeteria sells clean food with } \\
\text { affordable price. } \\
\text { 7. The availability of computer and internet } \\
\text { access. }\end{array}$ \\
\hline
\end{tabular}

\section{Classification of Service Quality Attributes into Kano Categories}

The service quality attributes are evaluated with the evaluation steps of Kano model. After having combined the answers to fulfillment and disfulfilment questions, the categories of the service attributes are listed in Table 3.

TABLE III: Kano CATEgories of SERVICE QUALITY ATtRIBUtes

\begin{tabular}{|c|c|c|c|c|c|c|c|c|c|}
\hline Attributes & A & O & M & I & R & Q & $\begin{array}{c}\text { A + O + } \\
\text { M })\end{array}$ & $\begin{array}{c}(\mathrm{I}+\mathrm{R}+ \\
\text { Q })\end{array}$ & $\begin{array}{c}\text { Kano } \\
\text { Category }\end{array}$ \\
\hline A1 & 90 & 123 & 100 & 71 & 0 & 0 & 313 & 71 & O \\
\hline A2 & 65 & 42 & 57 & 220 & 0 & 0 & 164 & 220 & I \\
\hline A3 & 100 & 45 & 158 & 81 & 0 & 0 & 303 & 81 & M \\
\hline A4 & 123 & 16 & 160 & 85 & 0 & 0 & 299 & 85 & M \\
\hline A5 & 99 & 34 & 161 & 90 & 0 & 0 & 294 & 90 & M \\
\hline B1 & 88 & 132 & 99 & 65 & 0 & 0 & 319 & 65 & O \\
\hline B2 & 85 & 145 & 90 & 64 & 0 & 0 & 320 & 64 & O \\
\hline B3 & 66 & 70 & 53 & 195 & 0 & 0 & 189 & 195 & I \\
\hline B4 & 70 & 120 & 104 & 90 & 0 & 0 & 294 & 90 & O \\
\hline B5 & 31 & 77 & 77 & 199 & 0 & 0 & 185 & 199 & I \\
\hline C1 & 44 & 45 & 100 & 195 & 0 & 0 & 189 & 195 & I \\
\hline C2 & 88 & 111 & 92 & 93 & 0 & 0 & 291 & 93 & O \\
\hline C3 & 100 & 99 & 93 & 92 & 0 & 0 & 292 & 92 & A \\
\hline C4 & 80 & 134 & 95 & 75 & 0 & 0 & 309 & 75 & O \\
\hline C5 & 90 & 129 & 82 & 83 & 0 & 0 & 301 & 83 & O \\
\hline C6 & 65 & 56 & 70 & 193 & 0 & 0 & 191 & 193 & I \\
\hline D1 & 48 & 66 & 75 & 195 & 0 & 0 & 189 & 195 & I \\
\hline D2 & 123 & 52 & 112 & 97 & 0 & 0 & 287 & 97 & A \\
\hline D3 & 69 & 133 & 83 & 99 & 0 & 0 & 285 & 99 & O \\
\hline D4 & 78 & 121 & 88 & 97 & 0 & 0 & 287 & 97 & O \\
\hline D5 & 68 & 67 & 53 & 196 & 0 & 0 & 188 & 196 & I \\
\hline D6 & 91 & 20 & 173 & 100 & 0 & 0 & 284 & 100 & M \\
\hline E1 & 84 & 30 & 180 & 89 & 1 & 0 & 294 & 90 & M \\
\hline E2 & 55 & 66 & 63 & 200 & 0 & 0 & 184 & 200 & I \\
\hline E3 & 169 & 13 & 112 & 90 & 0 & 0 & 294 & 90 & A \\
\hline E4 & 63 & 101 & 90 & 130 & 0 & 0 & 254 & 130 & O \\
\hline E5 & 83 & 34 & 156 & 111 & 0 & 0 & 273 & 111 & M \\
\hline E6 & 200 & 10 & 98 & 76 & 0 & 0 & 308 & 76 & A \\
\hline E7 & 140 & 20 & 123 & 96 & 5 & 0 & 283 & 101 & A \\
\hline
\end{tabular}

\section{Strategic Actions Based on Categories of refined Kano Model and Satisfaction Level}

Having obtained the results for degree of importance (on a scale of 1-5), these are then classified into two categories: (i) 'high' if the degree of importance is greater than the mean (4.03); and (ii) 'low' if the degree of importance is less than the mean. This also allows classification of the service quality attributes according to the refined Kano model. For the satisfaction level, these are also classified into two categories. If the satisfaction level value of an attribute is greater than the mean (3.42), then the attribute has 'high' satisfaction level, and it has 'low' satisfaction level if below the mean. The appropriate improving actions are proposed based on refined Kano categories and satisfaction level. All the analytic results are shown in Table 4.

TABLE IV: STRATEGIC IMPROVING ACTION

\begin{tabular}{|c|c|c|c|c|c|}
\hline Attributes & \begin{tabular}{|c|} 
Kano \\
Category \\
\end{tabular} & \begin{tabular}{|c|}
$\begin{array}{c}\text { Importance } \\
\text { degree }\end{array}$ \\
\end{tabular} & \begin{tabular}{|c|}
$\begin{array}{c}\text { Satisfaction } \\
\text { level }\end{array}$ \\
\end{tabular} & $\begin{array}{c}\text { refined Kano } \\
\text { Category } \\
\end{array}$ & $\begin{array}{c}\text { Improving } \\
\text { Actions } \\
\end{array}$ \\
\hline A1 & $\mathrm{O}$ & 4.12 & 3.43 & high value-added & $\begin{array}{c}\text { maintain the } \\
\text { service }\end{array}$ \\
\hline A2 & I & 4.22 & 3.12 & potential & \begin{tabular}{|c} 
improve the \\
service
\end{tabular} \\
\hline A3 & M & 4.13 & 3.03 & critical & \begin{tabular}{|c|}
$\begin{array}{c}\text { improve the } \\
\text { service }\end{array}$ \\
\end{tabular} \\
\hline A4 & $\mathrm{M}$ & 4.21 & 3.67 & critical & $\begin{array}{l}\text { maintain the } \\
\text { high service }\end{array}$ \\
\hline A5 & M & 4.22 & 3.73 & critical & $\begin{array}{l}\text { maintain the } \\
\text { high service }\end{array}$ \\
\hline B1 & $\mathrm{O}$ & 4.34 & 3.5 & high value-added & $\begin{array}{c}\text { maintain the } \\
\text { service }\end{array}$ \\
\hline B2 & $\mathrm{O}$ & 4.21 & 3.44 & high value-added & $\begin{array}{c}\text { maintain the } \\
\text { service }\end{array}$ \\
\hline B3 & I & 4.18 & 3.39 & potential & \begin{tabular}{|c} 
improve the \\
service
\end{tabular} \\
\hline B4 & $\mathrm{O}$ & 3.93 & 3.46 & low value-added & $\begin{array}{c}\text { retain an } \\
\text { acceptable } \\
\text { service level }\end{array}$ \\
\hline B5 & I & 3.82 & 3.67 & care-free & \begin{tabular}{|c|} 
continuously \\
offered but \\
reduce time \\
portion
\end{tabular} \\
\hline $\mathrm{C} 1$ & I & 3.99 & 3.11 & care-free & $\begin{array}{c}\text { continuously } \\
\text { done }\end{array}$ \\
\hline C2 & $\mathrm{O}$ & 4.11 & 3.33 & high value-added & $\begin{array}{l}\text { improve the } \\
\text { service level }\end{array}$ \\
\hline C3 & A & 3.89 & 3.38 & less attractive & \begin{tabular}{|c|}
$\begin{array}{c}\text { improve the } \\
\text { service }\end{array}$ \\
\end{tabular} \\
\hline $\mathrm{C} 4$ & $\mathrm{O}$ & 3.9 & 3.24 & low value-added & \begin{tabular}{|c|}
$\begin{array}{c}\text { improve the } \\
\text { service }\end{array}$ \\
\end{tabular} \\
\hline C5 & $\mathrm{O}$ & 4.13 & 3.67 & high value-added & $\begin{array}{l}\text { maintain the } \\
\text { high service }\end{array}$ \\
\hline C6 & I & 3.85 & 3.1 & care-free & $\begin{array}{c}\text { continuously } \\
\text { offered }\end{array}$ \\
\hline D1 & I & 3.77 & 3.22 & care-free & $\begin{array}{c}\text { continuously } \\
\text { done }\end{array}$ \\
\hline D2 & A & 4.27 & 3.56 & highly attractive & $\begin{array}{c}\text { raise the } \\
\text { service } \\
\text { performance }\end{array}$ \\
\hline D3 & $\mathrm{O}$ & 4.11 & 3.31 & high value-added & $\begin{array}{c}\text { improve the } \\
\text { service }\end{array}$ \\
\hline D4 & $\mathrm{O}$ & 3.92 & 3.61 & low value-added & $\begin{array}{c}\text { retain an } \\
\text { acceptable } \\
\text { service level }\end{array}$ \\
\hline D5 & I & 3.88 & 3.39 & care-free & $\begin{array}{c}\text { continuously } \\
\text { done }\end{array}$ \\
\hline D6 & M & 3.77 & 3.53 & necessary & \begin{tabular}{|c|} 
retain an \\
acceptable \\
service level \\
\end{tabular} \\
\hline E1 & M & 3.86 & 3.34 & necessary & $\begin{array}{c}\text { take } \\
\text { improvement } \\
\text { to attain an } \\
\text { acceptable } \\
\text { service level }\end{array}$ \\
\hline E2 & I & 3.76 & 3.03 & care-free & $\begin{array}{c}\text { continuously } \\
\text { done }\end{array}$ \\
\hline E3 & A & 4.13 & 3.45 & highly attractive & \begin{tabular}{|c} 
raise the \\
service \\
performance
\end{tabular} \\
\hline E4 & $\mathrm{O}$ & 3.78 & 3.75 & low value-added & $\begin{array}{c}\text { retain an } \\
\text { acceptable } \\
\text { service level }\end{array}$ \\
\hline E5 & M & 4.39 & 3.37 & critical & \begin{tabular}{|c|}
$\begin{array}{c}\text { improve the } \\
\text { service }\end{array}$ \\
\end{tabular} \\
\hline E6 & A & 3.76 & 3.67 & less attractive & reduce the \\
\hline
\end{tabular}




\begin{tabular}{|c|c|c|c|c|c|} 
& & & & & $\begin{array}{c}\text { price or } \\
\text { outsource }\end{array}$ \\
\hline E7 & A & 4.22 & 3.55 & highly attractive & $\begin{array}{c}\text { raise the } \\
\text { service } \\
\text { performance }\end{array}$ \\
\hline
\end{tabular}

\section{DisCUSSION}

For the purpose of this study, 5 higher education dimensions and 29 attributes are developed. The categories of these service attributes according to the refined Kano model are shown in column 5 of Table 4. Four service attributes are identified as 'critical' attributes. These are relevant \& up to date literature (A3), literature and lecture materials can be easily understood (A4), good \& understandable teaching performance (A5), and library provides up to date learning sources (E5). Six service attributes are categorized as 'highly value-added' attributes and three service attributes are identified as 'highly attractive' attributes. The 'highly value-added' attributes are a commitment to provide a service at the scheduled time (A1), important announcement is quickly informed to students (B1), always ready to help students (B2), students are equipped with good quality to work (C2), lecturers have the ability to answer questions from students (C5), and ease of obtaining lecture material (D3). The 'highly attractive' attributes are the availability of scholarship (D2), up to date equipments to support learning process (E3), and computer \& internet access (E7). Because these nine attributes (A1, B1, B2, C2, C5, D2, D3, E3, E7) have the potential to exert a significant effect on student satisfaction, the university should provide these at a high level of performance.

Among these nine items, the student-satisfaction levels of attributes A1, B1, B2, C5, D2, E3, and E7 are high (see column 4 of Table 4). It is thus apparent that the university should maintain their good performance with regard these seven services attributes as a high priority based on the considerations of the framework of the strategic decisions for improvement (see Fig. 2). But, the university can further raise the performance levels on attribute C2 (students are equipped with good quality to work) and attribute D3 (ease of obtaining lecture material), since their satisfaction levels are not very high. The appropriate improvement actions for these service attributes are listed in column 6 of Table 4 .

Among the highly important service attributes, attribute A2 (keep the records accurately) and B3 (clear notice) are classified as 'potential' attributes. This indicates that the students are not especially concerned about these service attributes, but that the offers are appreciated by many students. The university should improve the existing services on these attributes because their satisfaction levels are still low.

For the service attributes of low importance, there are four 'low value-added' attributes, only one 'less attractive' attribute, and six 'care-free' attributes (see column 5 of Table 4). The 'low value-added' attributes are attributes B4 (appropriate text books), C4 (safe environment), D4 (ease of administration), and E4 (clean environment). The 'less attractive' attribute is E6 (campus cafeteria). For this attributes, the price reduction thus has value to a significant proportion of student satisfaction. The six 'care-free' attributes are B5 (consultation time for students), C1 (lecturer competency), C6 (friendly environment), D1 (relevant and appropriate tasks), D5 (individual attention), and E2 (well-dressed and professional). These 'care-free' service attributes are not very concerned by the students and the provisions of these attributes are not very satisfied by the students.

\section{CONCLUSION}

Several challenges are associated with the identification of student needs. The challenges of the higher education institutions imply that service quality attributes are needed to satisfy (or even delight) the students. These service attributes are defined in the service strategy development and improvement. If one knows to what attributes influence the student satisfaction, and if one is aware of the relative critical of these service attributes and assessment from the student's perspective compared to the competitors, the satisfaction portfolio can be drawn up and suitable measures taken. The long-term objective is to raise the student satisfaction with regard to important service attributes in order to establish tenable competitive advantages.

Following the result, the priority of improvement actions can be made based on the students' preferences and satisfaction. As the first priority, the university has to improve the fulfillment level of the 'critical' attributes-for example, relevant and up to date literature and lecture material (A3) and up to date learning of the library (E5). The university also has to maintain the high service of the other 'critical' attributes, such as literatures and lecture materials that can be easily understood (A4) and good \& understandable teaching performance (A5).

This study makes an empirical contribution to the higher education research area. The methodology generated through its empirical case study suggests that there is evidence of good practices in service quality management within higher education sector. Although the present study has focused on higher education sector, the methodology can also be applied in other service industries-such as tourism and travel agents, banks, insurance companies, telecommunication providers, healthcare providers, and so on. In addition, the methodology can also be implemented in manufacturing industries.

\section{REFERENCES}

[1] F. Buttle, "SERVQUAL: review, critique, research agenda," European Journal of Marketing, vol. 30, no. 1, pp. 8-32, 1996.

[2] B.R. Lewis, "Quality in the service sector - a review," International Journal of Bank Marketing, vol. 7, no. 5, pp. 4-12, 1989.

[3] C.D. Moore, "Outclass the competition with service distinction," Mortgage Banking, vol. 47, no. 11, 1987.

[4] J. Horovitz, How to Win Customers - Using Customer Service for a Competitive Edge, Harlow: Longman, 1990.

[5] S.E. Pariseau and J.R. McDaniel, "Assessing service quality in school of business," International Journal of Quality \& Reliability Management, vol. 14, pp. 204-218, 1997.

[6] M. Joseph, M. Yakhou, and G. Stone, "An educational institution's quest for service quality: Customers' perspective,” Quality Assurance in Education, vol. 13, no. 1, pp. 66-82, 2005.

[7] Y. Hill, L. Lomas, and J. MacGregor, "Students' perceptions of quality in higher education," Quality Assurance in Education, vol. 11, no. 1, pp. 15-20, 2003. 
[8] B.Z. Butt and K. Rehman, "Examining the students satisfaction in higher education,” Procedia Social and Behavioral Sciences, vol. 2, pp. 5446-5450, 2010.

[9] A. Brochado, "Comparing alternative instruments to measure service quality in higher education," Quality Assurance in Education, vol. 17, no. 2, pp. 174-190, 2009.

[10] R.N. Nasser, B. Khoury, and K. Abouchedid, "University students' knowledge of services and programs in relation to satisfaction," Quality Assurance in Education, vol. 16, no. 1, pp. 80-97, 2006.

[11] R. Brown and T. Mazzarol, "The importance of institutional image to student satisfaction and loyalty within higher education," Higher Education, vol. 58, pp. 81-95, 2009.

[12] H. Kang and G. Bradley, "Measuring the performance of IT services: an assessment of SERVQUAL," International Journal of Accounting Information Systems, vol. 3, pp. 151-164, 2002.

[13] A. Parasuraman, V. A. Zeithaml, and L. L. Berry, "SERVQUAL: A multiple item scale for measuring consumer perceptions of service quality,” Journal of Retailing, vol. 64, no.1, pp. 13-40, 1988.

[14] N. Kano, N. Seraku, F. Takahashi, and S. Tsuji, "Attractive Quality and Must-be Quality," presented in 12th Annual Meeting of the Japan Society of Quality Control, 1984.

[15] C. C. Yang, "The application of two-dimensional quality model on service quality,” Quality Control Monthly, vol. 29, no. 5, pp. 27-33, 1993.

[16] C. C. Yang, "The refined Kano's model and its application,” Total Quality Management, vol. 16, no. 10, pp. 1127-1137, 2005.

[17] A. Parasuraman, V.A. Zeithaml, and L.L. Berry, "A conceptual model of service quality and its implications for future research," Journal of Marketing, vol. 49, no.4, pp. 41-50, 1985.

[18] C. Grönroos, "A service quality model and its market implications," European Journal of Marketing, vol.18, no. 4, pp. 36-44, 1984.

[19] A. Firdaus, "HEdPERF versus SERVPERF: The quest for ideal measuring instrument of service quality in higher education sector," Quality Assurance in Education, vol. 13, no. 4, pp. 305-328, 2005.

[20] R.K. Yeo, "Brewing service quality in higher education: characteristics of ingredients that make up the recipe," Quality Assurance in Education, vol. 16, no. 3, pp. 266-286, 2008.

[21] C.C. Yang, "Improvement actions based on the customers' satisfaction survey,” TQM \& Business Excellence, vol. 14, no. 8, pp. 919-930, 2003.

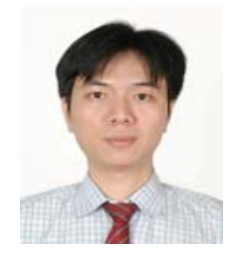

Ronald Sukwadi, was born in Kebumen, Indonesia in 1981. He received his Bachelor of Industrial Engineering (2002) and Master of Management (2004) from Diponegoro University Semarang, Indonesia. He is currently a $\mathrm{PhD}$ candidate in Industrial and Systems Engineering, Chung Yuan Christian University (CYCU), Taiwan. He is also a lecturer and researcher at Industrial Engineering Department of Atma Jaya Catholic University Jakarta, Indonesia. He has many papers published in international conferences, national conferences, and Indonesian journals. Mr. Sukwadi has been awarded "Best Paper Award" on the 8th ANQ Congress, New Delhi, India, 2010. His research interest includes industrial management area such as service quality, service science, marketing, and quality management.

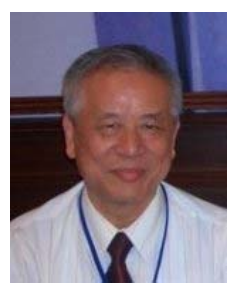

Ching-Chow Yang, is a Professor of Industrial \& Systems Engineering in Chung Yuan Christian University, Taiwan. He received his $\mathrm{PhD}$ in Management Science from the National Chiao Tung University, Taiwan. Prof. Yang was honored with the Individual Award of the ROC National Quality Awards in 1977. He is currently the President of Chinese Society for Quality (CSQ) Taiwan. He has published widely and served on the Editorial Board of The Service Industries Journal, TQM journal, Total Quality Management \& Business Excellence, Expert Systems with Applications, International Journal of Production Research, Human Systems Management, International Journal of Production Economic, Cornell Hospitality Quarterly, etc. His research interests include total quality management, strategy management, service quality, and Six Sigma. He is also a senior consultant for many well-known companies in Taiwan, China, Indonesia, and Vietnam.

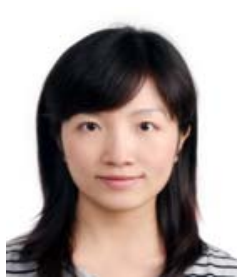

Fan Liu, was born in Changsha, China in 1984. She received her bachelor degree in English from the School of Foreign Languages, Chongqing Technology and Business University, China, 2006, and she received her master degree in Management Information Systems (MIS) from the School of Management, Kyung Hee University, Seoul, South Korea, 2009. She is currently a $\mathrm{PhD}$ candidate in the School of Management of Kyung Hee University, South Korea, where she teaches the course of Introduction to Management Information Systems. She worked as the secretariat for ANQ (Asian Network for Quality) during the year 2007 to 2009. Her research interests are focused in the field of e-Business, e-Commerce, Management Information Systems and quality management. Ms. Fan has many papers published in international conferences and she has been awarded "Best Paper Award" on the 6th ANQ Congress, Bangkok, Thailand, 2008. Her previous work has been published in Cyber psychology, Behavior, and Social Networking Journal. 